\title{
Acute Suppurative Necrotizing Pancholangitis
}

\section{A Case Report}

\author{
Magid M.A. Nasr ${ }^{a}$ Sami Asfar ${ }^{b}$ Ali Nur ${ }^{a}$ Ibrahim Wafai ${ }^{a}$ \\ Departments of Surgery, a Jahra Hospital and bMubarak Al-Kabeer Hospital, Faculty of Medicine, \\ Kuwait University, Kuwait
}

\section{Key Words}

Biliary system • Endoscopic retrograde cholangiogram . Cholangitis $\cdot$ Common bile duct $\cdot[\mathrm{A} 1]$

\begin{abstract}
Objective: To present a case of ascending cholangitis with resulting necrosis of the biliary system with perforation. Clinical Presentation and Intervention: A 40-yearold male patient presented with upper abdominal pain, fever and jaundice assessed clinically and investigated by laboratory and radiological tests. Endoscopic retrograde cholangiogram and surgery were performed. However, because of extensive suppurative pancholangitis involving most of the intrahepatic radicles, sound surgical drainage could not be accomplished. Unfortunately, the patient died 2 days after surgery. Conclusion: In this case of severe cholangitis, endoscopic and surgical interventions were not successful and might have contributed to the worsening of the condition.
\end{abstract}

Copyright $(2003$ S. Karger AG, Basel

\section{Introduction}

Biliary tract infection remains a cause of morbidity and at times mortality, despite major advances in management such as the use of new antibiotics [1]. Cholangitis is an infection of the biliary duct that occurs especially when there is an obstruction and usually improves with the use of appropriate antibiotics and after definitive surgery [2]. Occasionally, surgeons face an unusual case that deteriorates despite all interventions and may rapidly lead to a fatal outcome. We present such a case of acute necrotizing pancholangitis involving perforation of the biliary system.

\section{Case Report}

A 40-year-old male patient was admitted to Jahra Hospital, Kuwait, with upper abdominal pain and vomiting, and a history of such recurrent attacks in the last 4 years. He had a low-grade fever, and physical examination showed tenderness and guarding of the epigastrium and right hypochondrium. Clinical diagnosis was acute cholecystitis. Laboratory investigations showed a total leukocyte count (TLC) of $10.3 \times 10^{9} / 1$, serum amylase 696 U/1 (normal 25130), total bilirubin $28 \mu \mathrm{mol} / \mathrm{l}$ (normal 3-26), direct bilirubin $5 \mu \mathrm{mol} / \mathrm{l}$ (normal $0-4$ ), and normal alkaline phosphatase and other liver enzymes.

Abdominal ultrasound revealed acalcular cholecystitis with normal common bile duct (CBD). Conservative treatment was started by nasogastric tube and intravenous fluids, and broad spectrum antibiotics (Claforan, amikacin and Flagyl, which was later replaced with Tazocin). Two days later, the clinical condition remained the same, but the total bilirubin increased to $96 \mu \mathrm{mol} / 1$, direct bilirubin to $72 \mu \mathrm{mol} / 1$, alkaline phosphatase $140 \mathrm{IU} / \mathrm{l}$ (normal range 26-121), alanine aminotransferase $239 \mathrm{IU} / \mathrm{l}$ (normal range 10-60), aspartate aminotransferase $159 \mathrm{IU} / 1$ (normal range 10-42). Therefore endoscopic retrograde cholangiogram (ERC) was performed and showed slight dilatation of the CBD with biliary sludge, but no stones. Papillotomy was done to clear the sludge from the CBD. The patient's tempera-

\begin{tabular}{ll}
\hline KARGER & ( ) 2003 S. Karger AG, Basel \\
$1011-7571 / 03 / 0124-0269 \$ 19.50 / 0$ \\
$\begin{array}{l}\text { Fax +41613061234 } \\
\begin{array}{l}\text { E-Mail karger@karger.ch } \\
\text { www.karger.com }\end{array}\end{array}$ & $\begin{array}{l}\text { Accessible online at: } \\
\text { www.karger.com } / \mathrm{mpp}\end{array}$
\end{tabular}

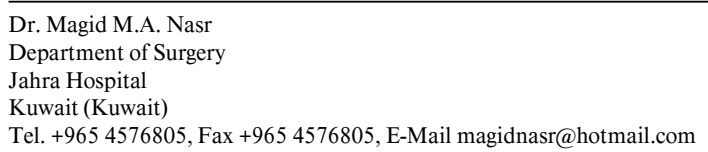


ture reached $38.5^{\circ} \mathrm{C}$, accompanied by rigors with a picture of cholangitis. TLC was $19.6 \times 10^{9} / 1$, and total bilirubin, direct bilirubin and alkaline phosphatase were further elevated to $152 \mu \mathrm{mol} / 1,98 \mu \mathrm{mol} / 1$ and $581 \mathrm{IU} / 1$, respectively.

Since the patient did not show any substantial clinical improvement, a repeat ERC was done, and indicated severe suppurative cholangitis. There was irregular filling of the intrahepatic biliary system with haziness and gas bubble mixed with contrast. The papillotomy was extended and the CBD was cleared of thick sludge. Nasobiliary drainage tubing was removed because there was no obstruction.

The patient did not improve and developed a picture of septic shock, with a temperature of $38.7^{\circ} \mathrm{C}$ and TLC of $23.2 \times 10^{9} / 1$. Total bilirubin rose to $198 \mu \mathrm{mol} / \mathrm{l}$, direct bilirubin to $133 \mu \mathrm{mol} / \mathrm{l}$, and alkaline phosphatase to $640 \mathrm{IU} / \mathrm{l}$.

The patient was resuscitated and laparotomy was performed to drain the CBD. During the operation a collection of infected bile in relation to Calot's triangle was found with disruption of the common hepatic duct (CHD) at its bifurcation. Both the CBD and CHD were necrotic with multiple perforations. There was no healthy duct up to or beyond the confluence of the hepatic duct. To get access to normal duct, both right and left hepatic ducts were dissected and followed into the liver parenchyma to the sectoral branches. Unfortunately the main bile duct and all dissected radicles were necrotic and sloughy. It was decided that no segment of bowel could be anastomosed to these necrotic ducts. Therefore the right and left hepatic ducts were catheterized and drained externally. The patient continued to deteriorate and died on the 3 rd postoperative day.

Swabs from the bile showed Pseudomonas infection. A specimen from the CBD wall showed histological features of acute necrotizing and partly hemorrhagic cholangitis.

\section{Discussion}

The most common cause of acute cholangitis is choledocholithiasis. Less common causes include malignant obstruction of the bile duct, strictures, biliary instrumentation, congenital abnormalities, parasitic infestation of the bile duct and acquired immune deficiency syndrome [3].

Bile is normally sterile in the absence of obstruction, but organisms can be cultured from more than $75 \%$ of patients who have bile duct stones [4]. The most common organisms are enteric in origin and include Escherichia coli, Klebsiella and Pseudomonas. Less common are grampositive cocci and anaerobes [5]. The pathway by which bacteria gain access to the bile duct is uncertain. Translocation from the gastrointestinal tract is one proposed pathway especially in obstructive jaundice, leading to portal vein bacteremia [6]. In cases with obstructive jaundice portal endotoxemia may be related to the absence of bile acids in the gut lumen, which are normally responsible for binding endotoxins in the gut [7]. Another pathway is probably ascending Aeromonas infection from the gastrointestinal tract, which may follow retrograde instrumentation of the bile duct [8].
Bacterial cholangitis is linked to intermittent obstruction due to biliary sludge in the CBD; recurrent passage of biliary sludge may precipitate obstructive inflammation and even fibrosis of Vater's ampulla and thus precipitate attacks of acute cholangitis [9]. Medical therapy with supportive measures and appropriate antibiotics are successful in $85 \%$ of patients with acute cholangitis [10]. For patients in whom initial management is not successful, biliary drainage is a life-saving procedure [11] and can be achieved either endoscopically, percutaneously or surgically. Endoscopic sphincterotomy was found to be associated with a complication rate of $28 \%$. Surgical intervention, however, was associated with a complication rate of $58 \%$. In addition, the mortality rate following endoscopic drainage is $5 \%$, compared to $21 \%$ after surgical drainage [12]. Lai et al. [13] found a mortality rate of $10 \%$ in the endoscopic drainage group, compared to $32 \%$ in the operative group. Accordingly it is generally accepted that emergency operative decompression of the biliary tract should be reserved for patients who do not respond to adequate medical therapy or nonoperative drainage [14].

The case presented here is unique because of the magnitude of necrosis as well as the multiple perforations in the CBD and CHD, which involved all of the intrahepatic and extrahepatic biliary radicles with complete slough and gangrene. The multiple perforations in the biliary system might have contributed to the infection. It is also possible that in addition to Pseudomonas, there might have been other virulent organisms that failed to grow in culture. Medical and endoscopic therapy failed to improve the symptoms of cholangitis, and in fact it is probable that endoscopy contributed to the worsening of the condition due to excessive manipulation and possibly the introduction of resistant nosocomial organisms in the already infected and compromised biliary tree, thereby leading to death as previously reported $[12,13]$. This case taught us a hard lesson not to push the patient for repeat ERC if there is no demonstrable obstruction from the first investigation.

\section{Conclusion}

The magnitude of the necrotizing pancholangitis that involved perforation of the biliary system was so great that neither endoscopic nor surgical decompression was successful. The timing of open surgical intervention in such a case of suppurative pancholangitis remains a difficult decision. 


\section{References}

1 Lillemoe KD: Surgical treatment of biliary tract infections. Am Surg 2000;66:138-144.

2 William JG, Neoptolemos JP: Cholangitis; in Tailor MB, Gollan JL, Steer ML, Wolfe M (eds): Gastrointestinal Emergencies (2nd edition). Baltimore, Williams and Wilkins, 1997, pp 275-288.

3 Martindale RG, Gadacyz TR: Biliary tract; in Shackelford RT, Zuidema GD (eds): Shackelford's Surgery of the Alimentary Tract, ed 4. Philadelphia, Saunders, 1996, pp 289-312.

4 Pitt Ha, Postier RG, Cameron JL: Consequences of preoperative cholangitis and its treatment on the outcome of surgery for choledocholithiasis. Surgery 1983;94:447-452.

5 Lee WJ, Chang KJ, Lee CS, Chen KM: Surgery in cholangitis: Bacteriology and choice of antibiotic. Hepatogastroenterology 1992;39:347349.
6 Deitch EA, Sittig K, Li M, Berg R, Specian RD: Obstructive jaundice promotes bacterial translocation from the gut. Am J Surg 1990;159:7984.

7 Pain JA, Cahill CJ, Bailey ME: Perioperative complications in obstructive jaundice. $\mathrm{Br} \mathrm{J}$ Surg 1985;73:775-778

8 Chan FK, Ching JY, Ling TK, Chung SC, Sung $\mathrm{JJ}$ : Aeromonas infection in acute suppurative cholangitis: Review of 30 cases. J Infect 2000; 40:69-73.

9 Grier JF, Cohen SW, Grafton WD, Ghalson $\mathrm{CF}$ : Acute suppurative cholangitis associated with choledochal sludge. Am J Gastroenterol 1994;89:617-619.

10 Boey JH, Way LW: Acute cholangitis. Ann Surg 1980;191:264-268.
11 Lin XZ, Chang KK, Shin JS, Lin CY, Lin PW, Yu CY, Chou TC: Emergency endoscopic nasobiliary drainage for acute calculous suppurative cholangitis and its potential use in chemical dissolution. J Gastroenterol Hepatol 1993; 8:35-38.

12 Leese T, Neoptolemos JP, Baker AR, CarrLocke DL: Management of acute cholangitis and the impact of endoscopic sphincterotomy. Br J Surg 1986;73:988-992.

13 Lai EC, Mok FP, Tan Es, Lo CM, Fan ST, You $\mathrm{KT}$, Wong J: Endoscopic biliary drainage for severe acute cholangitis. N Engl J Med 1992; 326:1582-1586.

14 Csendes A, Burdiles P, Diaz JC: Present role of classic open choledochostomy in the surgical treatment of patients with common bile duct stones. World J Surg 1998;22:1167-1170. 